\title{
Effect of Interleukin-4 on the Growth of Granulocyte- Macrophage Progenitor Cells Stimulated by Hematopoietic Growth Factors
}

\author{
Tadatsugu SATO', Masahiro MiSAGO'1, Jun-ichi TsukadA', Makoto KIKUChI, ${ }^{2}$ \\ Susumu ODA ${ }^{1}$, Shyozo CHIBA ${ }^{1,2}$ and Sumiya ETO ${ }^{1}$ \\ ${ }^{\prime}$ First Department of Internal Medicine, School of Medicine, University of Occupational and Environmental \\ Health, Japan. Kitakyushu 807, Japan \\ ${ }^{2}$ Division of Hematology, School of Medical Technology, University of Occupational and Environmental Health, Japan. \\ Kitakyushu 807, Japan
}

Abstract : The effects of recombinant murine interleukin- 4 (rmIL-4) on murine granulocyte-macrophage progenitor cells (CFU-GM) were investigated in the presence or absence of recombinant human granulocyte colony stimulating factor ( $\mathrm{rhG}-\mathrm{CSF}$ ), recombinant murine granulocyte-macrophage colony stimulating factor (rmGM-CSF) or recombinant murine interleukin-3 (rmIL-3) both in serum-free and serum-containing cultures. IL-4 alone could not support any GFU-GM colony formation in both culture systems. In serum-free cultures, IL-4 inhibited CFU-GM colony formation stimulated by G-CSF, GM-GSF or IL-3 from whole bone marrow cells (whole BM cells), nonadherent, nonphagocytic and $\mathrm{T}$ cell-depleted BM cells (fractionated BM cells) or whole BM cells of 5-Fluorouracil (5-FU) treated mice. On the other hand, in serumcontaining cultures, IL-4 inhibited CFU-GM colony formation stimulated by GM-CSF or IL-3, but IL-4 dose-dependently enhanced G-CSF-stimulated colony formation from both whole and fractionated BM cells. Morphological examinations revealed that IL-4 predominantly inhibited granulocyte-lineage colony formation stimulated by GM-CSF or IL-3 in both culture systems. When combined with G-CSF, IL-4 predominantly inhibited granulocyte-lineage colony formation and relatively increased macrophage-lineage colonies, but in serum-containing culture, IL-4 significantly increased macrophage-lineage colony formation. The results of the present study suggest that IL-4 has an inhibitory effect on the factors (G-CSF, GM-CSF, IL-3)dependent CFU-GM colony formation in serum-free condition and enhances only G-CSFstimulated CFU-GM colony formation in serum-containing condition.

Key words: IL-4, hematopoietic growth factors, GFU-GM, serum-free culture.

(Received 14 February 1990, accepted 27 March 1990)

\section{Introduction}

Differentiation and proliferation of hematopoietic progenitor cells require specific glycoproteins which are called colony stimulating factors (CSFs) (Clark \& Kamen, 1987). Recently, four types of murine or human CSFs are highly purified and recombinant products are prepared (Cannistra \& Griffin, 1988) - interleukin-3 (IL-3 or multi-CSF), granulocyte colony stimulating factor (G-CSF), granulocyte-macrophage colony stimulating factor 
(GM-CSF) and macrophage colony stimulating factor (M-CSF).

On the other hand, other cytokines such as interleukin-1 (IL-1), interleukin-4 (IL-4) and interleukin-6 (IL-6), which were originally defined by their functional activities, have been found to have enhancing activities on the differentiation and proliferation of myeloid cells (Cannistra \& Griffin, 1988; Metcalf, 1989).

IL-4/B-cell stimulatory factor-1 (BSF-1) was originally identified as a co-stimulator of the DNA synthesis in resting B-cells incubated with anti-IgM antibodies (Paul \& Ohara, 1987). Besides the actions on B cells, IL-4 has now been shown to stimulate the growth of $\mathrm{T}$ cells, to act as a co-stimulator for the proliferation of mast cells, and to affect the proliferation of hematopoietic stem cells. Peschel et al. (1987) showed that IL-4 alone did not support any colony formation, but the addition of $30 \mathrm{U} / \mathrm{ml}$ of IL-4 to G-CSF led to an increase in size and number (2 to 3 times) of granulocyte-colonies (G-colonies). Rennick et al. (1987) observed that IL-4 enhanced the CFU-GM (granulocyte-macrophage colony forming unit in culture) colony formation stimulated by G-CSF and M-CSF, but inhibited the IL-3dependent colony formation of granulocyte-macrophage progenitor cells (GFUGM). Broxmeyer et al. (1988) reported that IL-4 (more than $100 \mathrm{U} / \mathrm{ml}$ ) synergized with G-CSF, but not with GM-CSF, IL-3 or M-CSF to enhance the GFU-GM colony formation. In contrast, more recently, Kishi et al. (1989) showed that IL-4 alone could support GMcolonies, and that IL-4 was a multi-CSF similar to IL-3 and directly supported the proliferation of primitive hematopoietic progenitors. All these studies were carried out using culture medium containing serum.

Thus, it still remains unknown whether IL-4 itself supports the CFU-GM colony formation. Furthermore, because 10 to $30 \%$ of fetal calf serum (FCS) was used in culture systems of these reports, the possibility also still remains that FGS affects the CFU-GM colony formation. In this paper, we report the effects of recombinant murine IL-4 (rmIL-4) on the colony formation from murine BM cells in both serum-free and -containing agar culture systems. This analysis was carried out in the absence or presence of G-CSF, GMCSF or IL-3. Our results indicate that IL-4, when without serum, has an inhibitory effect on the factor-dependent colony formation of GFU-GM in serum-free condition, and has a synergistic effect with G-CSF in serum-containing condition.

\section{Materials and Methods}

Mice

Eight to 12 weeks old female BALB/c mice (Kyudo Co. Ltd., Tosu, Saga, Japan) were used in all experiments.

\section{Cell preparation}

Bone marrow (BM) nonadherent cells were obtained by culturing in plastic flasks. 1 $\times 10^{6}$ cells $/ \mathrm{ml}$ bone marrow cells suspended in Iscove's modified Dulbecco's tissue culture 
medium (IMDM; GIBCO Laboratories, Grand Island, NY) containing $10 \mathrm{mg} / \mathrm{ml}$ deionized Cohn fraction V BSA (Armour Pharmaceutical Co., Kankakee, IL) were incubated twice in plastic culture flasks (Falcon 3024; Becton Dickinson and Co., Oxnard, CA) for 60 min at $37^{\circ} \mathrm{C}$. Nonadherent cells obtained by rinsing were further incubated with $10 \% \mathrm{KAC}-2$; a silica suspension (Otsuka Bioassay Laboratories, Tokyo, Japan) for $60 \mathrm{~min}$ at $37^{\circ} \mathrm{C}$ to deplete phagocytic cells. After incubation, nonadherent and nonphagocytic cells were separated by density centrifugation using Lympholyte-M cell separation medium (Cedarlane Laboratories, Ontario, Canada), and washed twice with $10 \mathrm{mg} / \mathrm{ml} \mathrm{BSA} \mathrm{containing} \mathrm{IMDM.}$ T-cell depletion was performed by the treatment with monoclonal antibody and complement. To the pellet of $1 \times 10^{7}$ nonadherent and nonphagocytic cells prepared as described above, 1:500 diluted anti-Thy 1.2 monoclonal antibody (Cedarlane Laboratories) was added, and then the cells were incubated for $60 \mathrm{~min}$ at $4^{\circ} \mathrm{C}$. After the addition of lowTox-M Rabbit Complement (1:10, Cedarlane Laboratories), the cells were further incubated for $60 \mathrm{~min}$ at $37^{\circ} \mathrm{C}$. And then the viable cells were separated by Lympholyte-M cell separation medium and washed twice. These obtained cells were used as fractionated BM cells (nonadherent, nonphagocytic and $\mathrm{T}$ cell-depleted BM cells). The recovery of fractionated BM cells was usually less than $5 \%$ of the original $\mathrm{BM}$ cells and almost all these cells were viable as detected by a trypan-blue dye exclusion test. Routinely, the contamination of $\alpha$-Naphthyl Butyrate esterase staining positive cells in the final cell suspensions was less than $1 \%$.

\section{$B M$ cells of $5-F U$ treated mice}

5-fluorouracil (5-FU; Kyowa Hakko Kogyo Co. Ltd., Tokyo, Japan) was administered intravenously through the tail vein of mice at $150 \mathrm{mg} / \mathrm{kg}$. BM cells were harvested 4 days after 5-FU injection. The progenitor cells in these BM cells were highly enriched for the dormant primitive hematopoietic progenitors (Hodgson \& Bradley, 1979; Stanley et al., 1986).

\section{Reagents}

RmIL-4 was kindly provided by Ono Pharmaceutical Co. (Osaka, Japan). It had a specific activity of $1 \times 10^{8} \mathrm{U} / \mathrm{mg}$ protein by an anti-IgM costimulation assay (Severinson et al., 1987). RmIL-3 was purchased from Genzyme Corporation (Boston, MA). It had a specific activity of $10^{7} \mathrm{U} / \mathrm{mg}$ by proliferation assay using IL-3 dependent FDC-P2 cells (Prestidge et al., 1984). RhG-CSF was generously provided by Chugai Pharmaceutical Co. (Tokyo, Japan), and had a specific activity of $2 \times 10^{8} \mathrm{U} / \mathrm{mg}$ (Nagata et al., 1986; Tsuchiya $e t$ al., 1987). RmGM-CSF was also provided by Sumitomo Pharmaceutical Co. (Osaka, Japan). It had a specific activity of $5 \times 10^{8} \mathrm{U} / \mathrm{mg}$. One unit of activity is defined as the amount required to stimulate formation of one CFU-GM colony in soft agar cultures with $7.5 \times 10^{4}$ murine whole BM cells (Prestidge et al., 1984). RhG-CSF has no species specificity, and so, it is fully available for studying in culture systems for murine cells (Zsebo et al., 
1986).

Each factor was plated alone in whole $\mathrm{BM}$ cultures over various dose ranges (rmGMCSF, $0-100 \mathrm{ng} / \mathrm{ml}$; rhG-CSF, $0-100 \mathrm{ng} / \mathrm{ml}$; rmIL-3, 0-400 U/ml) and a plateau dose of each factor was determined from dose-responsive curves of total colony formation at 4 days of culture. These doses were used alone or in combination. The doses used were 0.1 $\mathrm{ng} / \mathrm{ml}$ for $\mathrm{rmGM}$-CSF, $20 \mathrm{ng} / \mathrm{ml}$ for $\mathrm{rhG}-\mathrm{CSF}$ or $200 \mathrm{U} / \mathrm{ml}$ for $\mathrm{rmIL}-3$, respectively.

\section{CFU-GM colony assay \\ Serum-free culture}

A serum-free culture system was performed using the method of Stewart et al. (1984) with some modifications (Sato et al., 1988). $1 \times 10^{5}$ cells $/ \mathrm{ml}$ of whole BM cells of normal or 5 -FU treated mice, or $4 \times 10^{ \pm}$cells $/ \mathrm{ml}$ of fractionated $\mathrm{BM}$ cells, were cultured in $35 \times 10$ mm plastic Petri dishes (Falcon 3001) containing IMDM with $0.3 \%$ agar (Difco Laboratories, Detroit, MI), $10 \mathrm{mg} / \mathrm{ml}$ deionized Cohn fraction V BSA, $388 \mu \mathrm{g} / \mathrm{ml}$ human transferrin (Sigma Chemical Co., St. Louis, MO) saturated with $\mathrm{FeCl}_{3}, 7.8 \mu \mathrm{g} / \mathrm{ml}$ cholesterol (Wako Pure Chemical Industries, Osaka, Japan), $7.5 \times 10^{-5} \mathrm{M} 2$-mercaptoethanol (2ME; Wako) and various concentrations of IL-4 with or without IL-3, G-CSF or GMCSF. Cells were cultured for 7 days at $37^{\circ} \mathrm{C}$ in a humidified atmosphere of $5 \% \mathrm{CO}_{2}$. When BM cells of 5-FU treated mice were used, cells were cultured for 12 days under the same conditions as described above.

A CFU-GM colony was defined as an aggregate consisting of more than 40 cells. If an aggregate consisted of 10 to 40 cells, it was scored as a cluster. In situ esterasedouble staining was performed by the techniques previously described for identifying the colony types (Tsukada et al., 1987). Briefly, Whatman \# 1 filter paper disks were placed over the agar layer in the Petri dish, and the agar was dried by blowing cold air over it until the filter paper was dry. The fine agar film was stained by using esterase staining kits (Muto Chemical Co. Ltd., Tokyo, Japan).

We previously reported that in these serum-free cultures, CFU-GM colony formation from whole BM cells was supported at the same degree in serum-containing (FCS 20\%) cultures when stimulated by serum-free pokeweed mitogen-stimulated spleen cell conditioned medium (PWM-SCM) (Sato et al., 1988).

\section{Serum-containing culture}

$1 \times 10^{5} \mathrm{BM}$ cells were cultured in Petri dishes containing IMDM with $0.3 \%$ agar, $20 \%$ FCS (Boehring Mannheim GmbH, West Germany), $6 \times 10^{-5} \mathrm{M} 2 \mathrm{ME}$ and the reagents described above. After incubation under the same conditions as those in serum-free cultures, colonies were counted and stained. In some experiments, the concentration of FCS was increased up to $40 \%$. 


\section{Statistics}

All experiments were repeated at least three times, and the representative results are given here. Results are expressed as Mean $\pm \mathrm{SE}$ of triplicate cultures. The Student's $t$ test was used to determine the statistical significance.

\section{Results}

Effect of IL-4 on CFU-GM colony formation from whole BM cells in serum-containing cultures

Whole murine BM cells were cultured for 7 days at FGS concentrations of either $20 \%$ or $40 \%$ with various doses of IL-4. Each concentration of IL-4 up to $500 \mathrm{U} / \mathrm{ml}$ could support only a few clusters but not a colony at FCS concentrations up to $40 \%$ (data not shown). These observations indicate that IL-4 itself does not have any CFU-GM colony supporting ability even in the presence of serum.

Effect of IL-4 on CFU-GM colony formation from whole BM cells with or without respective G-CSF and GM-CSF in serum-free cultures

IL-4 could not support any GFU-GM colonies in serum-free cultures (Fig. 1), as it did in serum-containing cultures. Therefore, various doses of IL-4 were added to serum-free cultures of a CFU-GM colony stimulated by an optimal dose of either G-CSF or GM-CSF to elucidate the synergistic effect of IL-4 (Fig. 1). IL-4 inhibited CFU-GM colony forma-

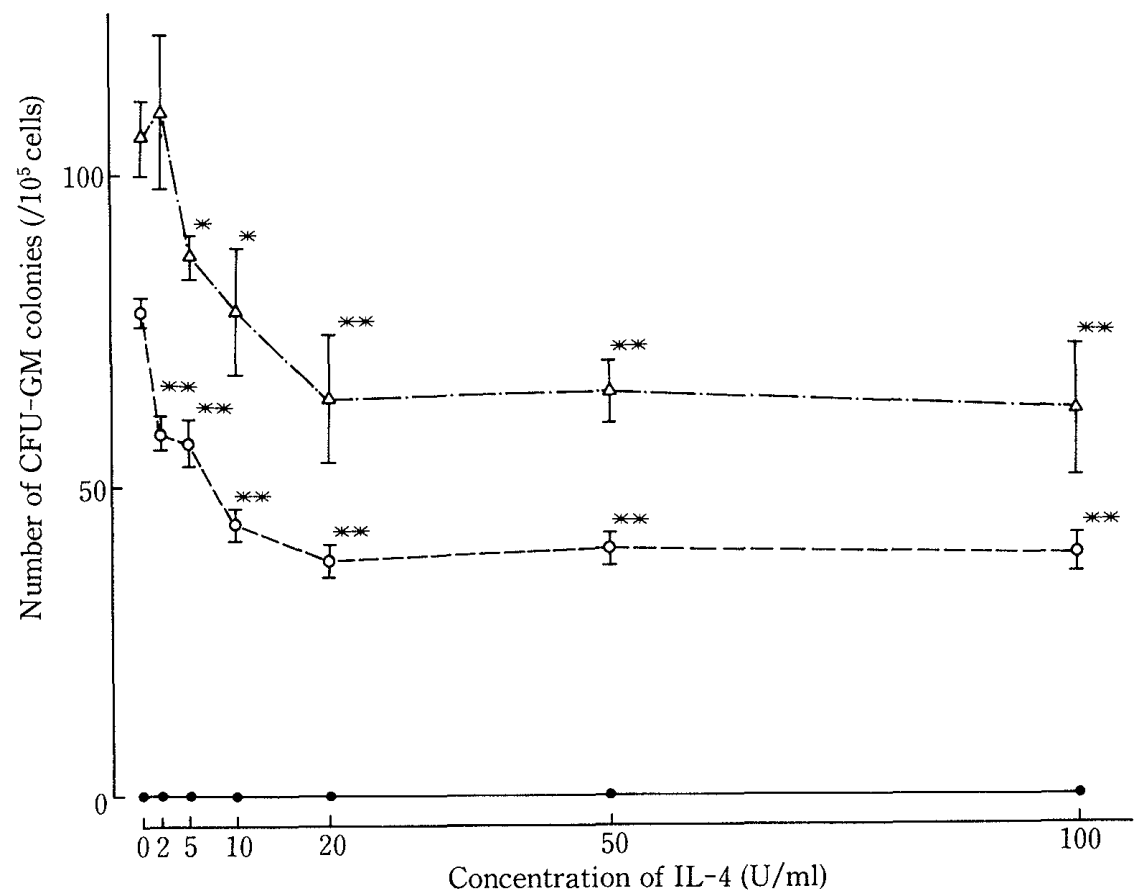

Fig. 1. Effect of IL-4 on CFU-GM colony formation from whole BM cells in serum-free cultures. CFU-GM colony formation stimulated by IL-4 alone (O), IL-4 with $20 \mathrm{ng} / \mathrm{ml}$ of G-CSF $(\bigcirc)$ or $0.1 \mathrm{ng} / \mathrm{ml}$ of GM-CSF $(\triangle)$ were studied. Each point represents Mean $\pm \mathrm{SE}$ of triplicate cultures. $\quad *=P<0.05, * *=P<0.01$ when compared with control values (IL-4 not added). 
tion stimulated by G-CSF dose-dependently, and also inhibited GFU-GM colony formation by GM-CSF. The maximum inhibitory effect of IL-4 on G-CSF- or GM-CSF-dependent GFU-GM colony formation was observed at more than $20 \mathrm{U} / \mathrm{ml}$ of IL-4, respectively.

Effect of IL-4 on factor (G-CSF, GM-CSF or IL-3)-dependent CFU-GM colony formation from fractionated BM cells in serum-free and serum-containing cultures

To elucidate whether the inhibitory effect of IL-4 on CFU-GM colony formation was direct action or indirect action through the accessory cells, nonadherent, nonphagocytic and T cell-depleted BM cells (fractionated BM cells) were used as target cells against IL-4, and the results in serum-free cultures were compared with those in serum-containing cultures (Table 1). The addition of $50 \mathrm{U} / \mathrm{ml}$ of IL-4 to the optimal concentrations of G-CSF, GMCSF or IL-3 inhibited CFU-GM colony formation from fractionated BM cells in serum-free cultures. In serum-containing cultures, IL-4 also inhibited GM-CSF- or IL-3-dependent GFU-GM colony formation. However, IL-4 enhanced GFU-GM colony formation stimulated by G-CSF by 2 to 3 fold. This enhancing effect was also observed in GFU-GM colony formation from whole $\mathrm{BM}$ cells in serum-containing cultures (data not shown). Morphological examinations revealed that IL-4 inhibited mainly granulocyte-lineage colony

Table 1. GFU-GM colony formation from fractionated bone marrow cells and types of colonies formed in serum-free and -containing (FCS 20\%) cultures

\begin{tabular}{|c|c|c|c|c|c|}
\hline & & \multirow{2}{*}{$\begin{array}{l}\text { Total colony } \\
\text { number } \\
\left(/ 4 \times 10^{4} \text { cells }\right)\end{array}$} & \multicolumn{3}{|c|}{ Types of colonies } \\
\hline & & & G & $\mathrm{G} / \mathrm{M}$ & M \\
\hline \multicolumn{6}{|c|}{ serum-free cultures } \\
\hline G-CSF & & $71 \pm 3.6$ & 21 & 36 & 14 \\
\hline G-CSF & + IL-4 & $46 \pm 6.2^{*}$ & 1 & 14 & 31 \\
\hline GM-CSF & & $221 \pm 22.4$ & 0 & 73 & 148 \\
\hline GM-CSF & + IL-4 & $150 \pm 5.9^{*}$ & 0 & 20 & 131 \\
\hline IL-3 & & $247 \pm 6.1$ & 20 & 82 & 146 \\
\hline IL-3 & + IL-4 & $37 \pm 4.4^{*}$ & 2 & 7 & 28 \\
\hline \multicolumn{6}{|c|}{ serum-containing cultures } \\
\hline G-CSF & & $60 \pm 4.4$ & 18 & 36 & 6 \\
\hline $\mathrm{G}-\mathrm{CSF}$ & + IL-4 & $148 \pm 4.7^{*}$ & 0 & 44 & 104 \\
\hline GM-CSF & & $400 \pm 6.2$ & 20 & 160 & 220 \\
\hline GM-CSF & + IL-4 & $280 \pm 6.4^{*}$ & 14 & 56 & 210 \\
\hline IL-3 & & $418 \pm 9.3$ & 20 & 230 & 168 \\
\hline IL-3 & $+\mathrm{IL}-4$ & $202 \pm 3.4^{*}$ & 0 & 40 & 162 \\
\hline
\end{tabular}

Additional effects of IL-4 to G-CSF, GM-GSF and IL-3 were investigated for CFU-GM colony forming ability from fractionated bone marrow cells. The concentration of each growth factor was $20 \mathrm{ng} / \mathrm{ml}$ for G-CSF, $0.1 \mathrm{ng} / \mathrm{ml}$ for GM-CSF and $200 \mathrm{U} / \mathrm{ml}$ for IL-3, respectively, in which the numbers of CFU-GM colonies formed from whole bone marrow cells reached at plateau level. IL-4 was used at the concentration of $50 \mathrm{U} / \mathrm{ml}$. Values are represented as Mean $\pm \mathrm{SE}$ of triplicate cultures. $\quad *=P<0.01$ when compared with control values (IL-4 not added). 
formation, but not macrophage-lineage colony formation and that the ratio of macrophagelineage colonies was relatively increased when BM cells were stimulated by IL-3 or GMCSF in combination with IL-4. However, when combined with G-CSF, IL-4 absolutely increased macrophage-lineage colony formation in serum-containing cultures. In serumfree cultures, IL-4 combined with G-CSF inhibited granulocyte-lineage colony formation, as it did when combined with IL-3 or GM-CSF. These results strongly suggest that the inhibitory effect of IL-4 on factor-dependent GFU-GM colony formation from BM cells is not affected by adherent cells, phagocytic cells and T cells, and that IL-4 acts as an enhancing factor on G-CSF-dependent GFU-GM colony formation under the presence of serum.

Effect of IL-4 on factor (G-CSF, GM-CSF or IL-3)-dependent CFU-GM colony formation from BM cells of 5-FU-treated mice in serum-free cultures

It was reported that Thy-1 is an antigen found not only on mature and immature $\mathrm{T}$ cells, but also on mouse hematopoietic stem cells including CFU-GM (Miller et al., 1985). Therefore, the procedure of anti-Thy 1.2 antibody and complement treatment may cause the depletion of some special populations of GFU-GM. To obtain the whole population of

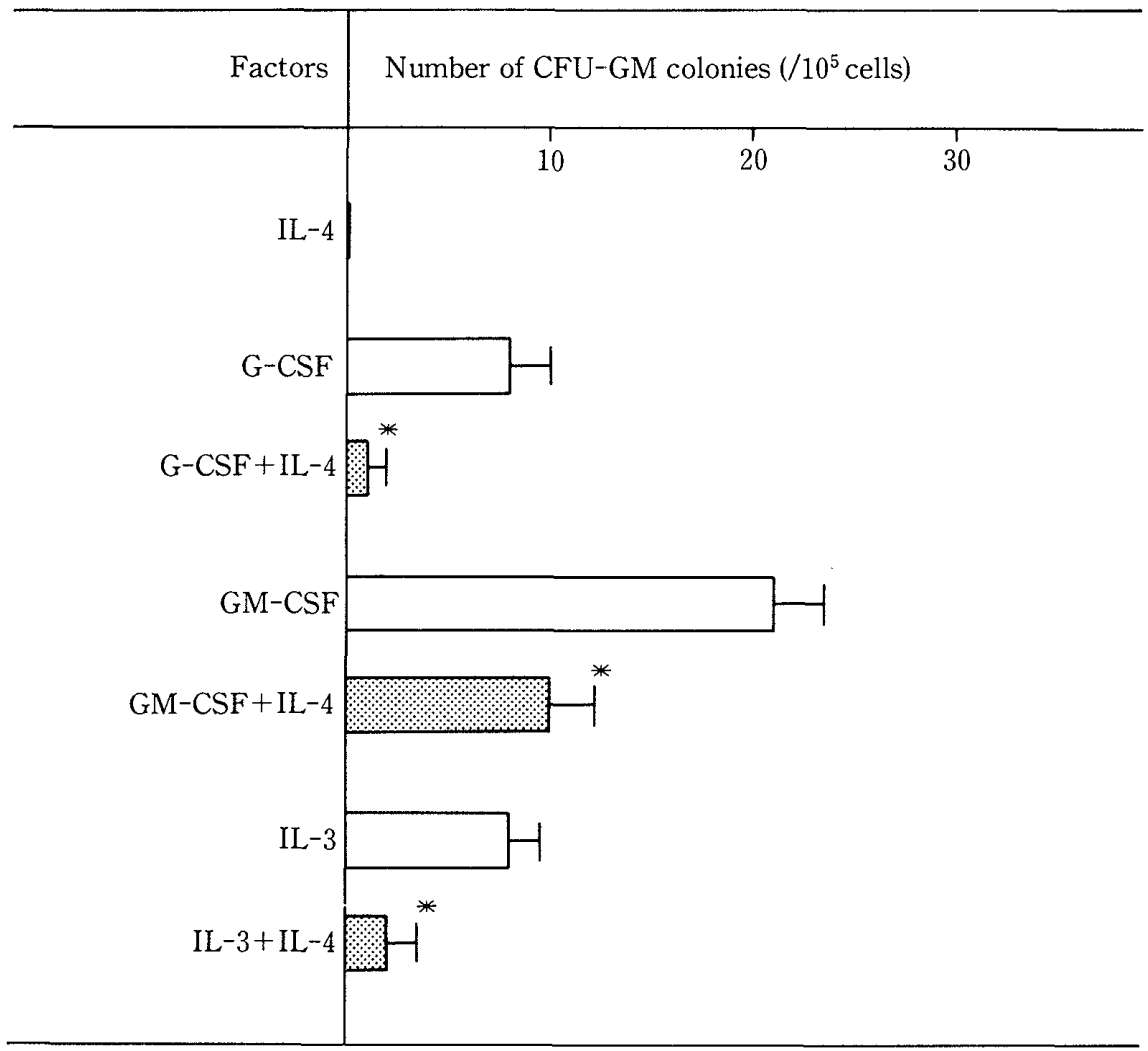

Fig. 2. Effect of IL-4 on CFU-GM colony formation from BM cells treated with 5-FU 4 days previously in serum-free cultures. Various factors alone and in combination with $50 \mathrm{U} / \mathrm{ml}$ of IL-4 were studied. The doses used were $20 \mathrm{ng} / \mathrm{ml}$ for G-CSF, $0.1 \mathrm{ng} / \mathrm{ml}$ for GM-GSF or $200 \mathrm{U} / \mathrm{ml}$ for IL-3, respectively. Each point represents Mean $\pm \mathrm{SE}$ of triplicate cultures scored on day 12 of culture. $*=P<0.01$ when compared with control values (IL-4 not added). 


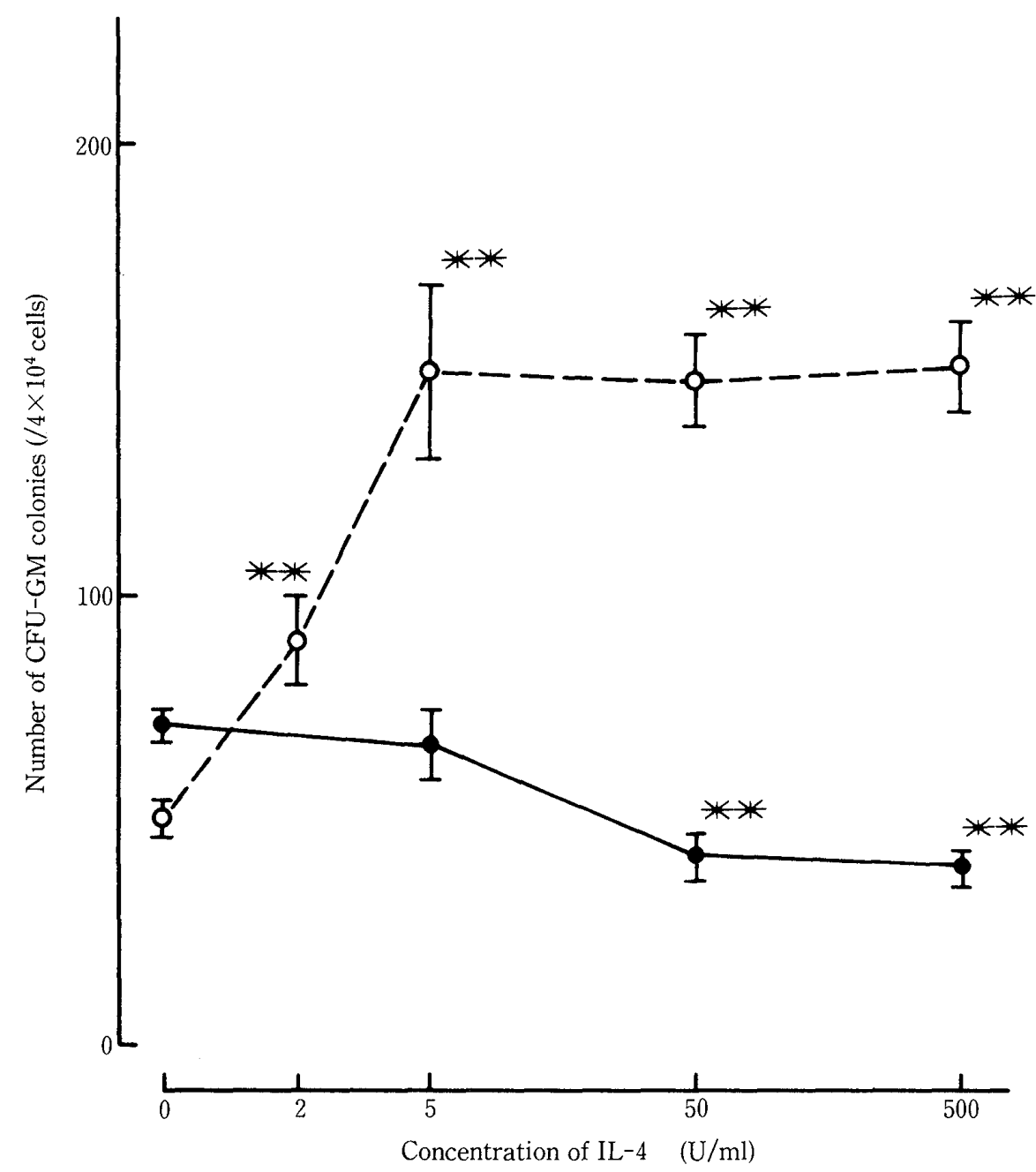

Fig. 3. Effect of IL-4 on CFU-GM colony formation from fractionated BM cells. BM cells were stimulated by various doses of IL- 4 with $20 \mathrm{ng} / \mathrm{ml}$ of G-CSF both in serum-free (O) cultures and in serum-containing $(O)$ cultures (FCS 20\%). Each point represents Mean $\pm \mathrm{SE}$ of triplicate cultures. $*=P<0.05, * *=P<0.01$ when compared with control values (IL-4 not added).

GFU-GM, BM cells were prepared from mice injected with 5-FU 4 days previously. Figure 2 shows that IL-4 inhibits CFU-GM colony formation stimulated by either G-CSF, GM-CSF or IL-3 from 5-FU-treated BM cells in serum-free cultures. This indicates that IL-4 truly inhibits the factor-dependent GFU-GM colony formation in the serum-free culture system.

Dose-responsive curves of addition of $I L-4$ to $G$-CSF-stimulated CFU-GM colony formation from fractionated BM cells in serum-free and -containing cultures

IL-4 had different effects on CFU-GM colony formation in serum-free cultures and in serum-containing cultures when combined with G-CSF, as shown in Table 1. Therefore, the dose-responsive effect of added IL-4 to G-CSF stimulated-CFU-GM colony formation from fractionated BM cells in serum-free or -containing cultures was studied. IL-4 syner- 
gistically stimulated CFU-GM colony formation with G-CSF in serum-containing cultures by 2 to 3 fold, but inhibited dose-responsively G-CSF-dependent CFU-GM colony formation in serum-free cultures (Fig. 3).

These results indicate that IL-4 requires the presence of serum to synergize with GCSF.

\section{Discussion}

In this study, it was shown that IL-4 alone was incapable of stimulating CFU-GM colony formation, and inhibited the factors-dependent GFU-GM colony formation, especially granulocyte-lineage colony formation, in serum-free cultures. Several investigators also reported that IL-4 alone was unable to form CFU-GM colonies (Peschel et al., 1987; Rennick et al., 1987; Broxmeyer et al., 1988). But Kishi et al. (1989) recently reported that IL-4 itself could support GM-colony formation at the concentrations of more than $100 \mathrm{U} / \mathrm{ml}$ from whole murine bone marrow cells in 30\% FCS contained cultures. Their results are in direct conflict with the previous results and ours. They considered that the differences of their results might be due to the FCS concentration in the culture system, because they studied under the condition of FCS 30\%, which was higher than that of previous reports. In the present study, we carried out the experiments using serum-containing cultures at FCS concentrations up to $40 \%$, and showed that IL-4 could not support any CFU-GM colony formation even at the concentration of $500 \mathrm{U} / \mathrm{ml}$. The reason for the differences between their results and ours is still unclear. It may be due to the difference of the batches of FCS because serum is considered to contain various identified and/or unidentified factors which affect the colony forming ability (Dainiak, 1985). Therefore, special batches of FCS, which are able to support large numbers of colonies, are selected for studying in vitro colony formation (Metcalf, 1984).

Our results indicate that IL-4 dose-dependently inhibits the factor-dependent CFU-GM colony formation stimulated by IL-3, GM-CSF and G-CSF in serum-free cultures, and that those inhibitory effects are also observed in CFU-GM colony formation from nonadherent, nonphagocytic and $\mathrm{T}$ cell-depleted $\mathrm{BM}$ cells and from $\mathrm{BM}$ cells of 5-FU treated mice. Previous reports indicated that IL-4 augmented CFU-GM colony formation when combined with G-CSF (Peschel et al., 1987; Rennick et al., 1987; Broxmeyer et al., 1988). In our study in serum-containing cultures, we also showed that IL-4 combined with G-CSF stimulated synergistically CFU-GM colony formation. However, in serum-free cultures, IL-4 inhibited G-CSF-dependent CFU-GM colony formation dose-dependently. It is still unclear why the effects of IL-4 on G-CSF-dependent CFU-GM colony formation were different in serum-containing and -free cultures. In serum-containing cultures, the involvement of unidentified serum-borne factors in CFU-GM colony formation cannot be excluded, and so, it appears that some factors in the serum may act with IL-4 synergistically. It may be also concluded that hematopoietic factors are stage-specific, and so, the combination of 
several hematopoietic growth factors may be required for the optimal colony formation in serum-free cultures (Kishi et al., 1989; Sonoda et al., 1988).

As for the indirect mechanism of the inhibitory effect of IL-4, Peschel et al. (1989) showed that IL-4 induced inhibitory activity in BM-derived stromal cell monolayers, and they supposed that macrophages in stromal layers may release an inhibitory substance in the presence of IL-4. Indeed, IL-4 has direct influences on macrophages (Crawford et al., 1987; Zlotnik et al., 1987) and our results also indicate that IL-4 relatively preserve macrophage-lineage colonies. But, recently, it is indicated that IL-4-activated monocytes from peripheral blood can secrete G-CSF and M-CSF (Wieser et al., 1989) and that IL-4 inhibits the production of tumor necrosis factor- $\alpha$, which inhibits CFU-GM colony formation stimulated by hematopoietic growth factors (Broxmeyer \& Williams, 1988), from lipopolysaccharide stimulated monocytes (Hart et al., 1989). Therefore, more detailed studies are required to clarify the role of macrophages in the IL-4 mediated inhibitory effect on progenitor cells in vitro.

We conclude that IL-4 has unique bipotential effects, mainly inhibitory and synergistic in some aspects, on CFU-GM. Thus, from our results that IL-4 inhibits the factordependent CFU-GM colony formation with either G-CSF, GM-CSF or IL-3 in serum-free cultures, it can be stated that IL-4 is added as a new factor to the previously described myelo-suppressive factors, such as prostaglandins, lactoferrin, interferons and tumor necrosis factor (Broxmeyer \& Williams, 1988). Although further studies are required to clarify the role of IL-4 in granulopoiesis, the results reported by us and others indicate that IL-4 is an important regulator of hematopoiesis.

\section{References}

Broxmeyer, H. E., Lu, L., Cooper, S. et al. (1988): Synergistic effects of purified recombinant human and murine B cell growth factor-1/IL-4 on colony formation in vitro by hematopoietic progenitor cells. Multiple actions. J. Immunol., 141: 3852-3862.

Broxmeyer, H. E. \& Williams, D. E. (1988): The production of myeloid blood cells and their regulation during health and disease. CRC Crit. Rev. Oncol/Hematol., 8: 173-226.

Cannistra, S. A. \& Griffin, J. D. (1988): Regulation of the production and function of granulocytes and monocytes. Seminars in Hematol., 25: 173-188.

Clark, S. G. \& Kamen, R. (1987): The human hematopoietic colony-stimulating factors. Science, 236: $1229-1237$.

Crawford, R. M., Finbloom, D. S., Ohara, J. et al. (1987): B cell stimulatory factor-1 (interleukin 4) activates macrophages for increased tumoricidal activity and expression of Ia antigens. J. Immunol., 139: $135-141$

Dainiak, N. (1985): Role of defined and undefined serum additives to hematopoietic stem cell culture. In: Hematopoietic Stem Cell Physiology. (Cronkite, E. P. et al., ed.). Alan R. Liss, Inc., New York. pp. $59-76$.

Hart, P. H., Vitti, G. F., Burgess, D. R. et al. (1989): Potential antiinflammatory effects of interleukin 4: Suppression of human monocyte tumor necrosis factor $\alpha$, interleukin 1, and prostaglandin E2. Proc. Natl. Acad. Sci. USA, 86: 3803-3807. 
Hodgson, G. S. \& Bradley, T. R. (1979): Properties of hematopoietic stem cells surviving 5-fluorouracil treatment: Evidence for a pre-CFU-S cell? Nature, 281: 381-382.

Kishi, K., Ihle, J. N., Urdal, D. L. et al. (1989): Murine B-cell stimulatory factor-1 (BSF-1)/interleukin-4 (IL-4) is a multilineage colony-stimulating factor that acts directly on primitive hemopoietic progenitors. J. Cell. Physiol., 139: 463-468.

Metcalf, D. (1984): Techniques for the clonal culture of hemopoietic cells. In: The Hemopoietic Colony Stimulating Factors. (Metcalf, D., ed.). Elsevier, Amsterdam. pp. 97-150.

Metcalf, D. (1989): Peptide regulatory factors. Haemopoietic growth factors 1. Lancet, 15: 825-827.

Miller, B. A., Lipton, J. M., Linch, D. C. et al. (1985): Thy-1 is a differentiation antigen that characterizes immature murine erythroid and myeloid hematopoietic progenitors. J. Cell. Physiol., 123: 25-32.

Nagata, S., Tsuchiya, M., Asano, S. et al. (1986): Molecular cloning and expression of cDNA for human granulocyte colony-stimulating factor. Nature, 319: 415-418.

Paul, W. E. \& Ohara, J. (1987): B-cell stimulatory factor-1/interleukin 4. Ann. Rev. Immunol., 5: 429459.

Peschel, P., Paul, W. E., Ohara, J. et al. (1987): Effects of B cell stimulatory factor-1/interleukin 4 on hematopoietic progenitor cells. Blood, 70: 254-263.

Peschel, C., Green, I. \& Paul, W. E. (1989): Interleukin-4 induces a substance in bone marrow stromal cells that reversibly inhibits factor-dependent and factor-independent cell proliferation. Blood, 73: 11301141 .

Prestidge, R. L., Watson, J. D., Urdal, D. L. et al. (1984): Biochemical comparison of murine colonystimulating factors secreted by a T cell lymphoma and a myelomonocytic leukemia. J. Immunol., 133: 293-298.

Rennick, D., Yang, G., Muller-Sieburg, C. et al. (1987): Interleukin 4 (B-cell stimulatory factor 1) can enhance or antagonize the factor-dependent growth of hemopoietic progenitor cells. Proc. Natl. Acad. Sci. USA., 84: 6889-6893.

Sato, T., Misago, M., Tsukada, J. et al. (1988): The effect of purified mouse GM-CSF on CFU-C colony growth in serum-free cultures. J. UOEH., 10: 289-296. (in Japanese)

Severinson, E., Naito, T., Tokumoto, H. et al. (1987): Interleukin 4 (IgGı induction factor): a multifunctional lymphokine acting also on T cells. Eur. J. Immunol., 17: 67-72.

Sonoda, Y., Yang, Y. G., Wong, G. G. et al. (1988): Analysis in serum-free culture of the targets of recombinant human hemopoietic growth factors: Interleukin 3 and granulocyte/macrophage-colonystimulating factor are specific for early developmental stages. Proc. Natl. Acad. Sci. USA, 85: 43604364.

Stanley, E. R., Bartocci, A., Patinkin, D. et al. (1986): Regulation of very primitive, multipotent, hemopoietic cells by hemopoietin-1. Cell, 45: 667-674.

Stewart, S., Zhu, B. \& Axelrad, A. (1984): A "serum-free" medium for the production of erythropoietic bursts by murine bone marrow cells. Exp. Hematol., 12: 309-318.

Tsuchiya, M., Nomura, H., Asano, S. et al. (1987): Characterization of recombinant human granulocytecolony-stimulating factor produced in mouse cells. EMBO J., 6: 611-616.

Tsukada, J., Misago, M., Sato, T. et al. (1987): The effect of recombinant erythropoietin on murine megakaryocyte colony formation. Int. J. Cell Cloning., 5: 401-411.

Wieser, M., Bonifer, R., Oster, W. et al. (1989): Interleukin-4 induces secretion of CSF for granulocyte and CSF for macrophages by peripheral blood monocytes. Blood, 73: 1105-1108.

Zlotnik, A., Fischer, M., Roehm, N. et al. (1987): Evidence for effects of Interleukin 4 (B cell stimulatory factor 1) on macrophages: enhancement of antigen presenting ability of bone marrow-derived macrophages. J. Immunol., 12: 4275-4279.

Zsebo, K. M., Cohen, A. M., Murdock, D. C. et al. (1986): Recombinant human granulocyte colony stimulating factor: Molecular and biological characterization. Immunobiology, 172: 175-184. 
インターロイキン 4 の造血因子刺激顆粒球・マクロファージ系前駆細胞増殖に対する 效果

佐藤 忠嗣 1 三石砂 將裕 ${ }^{1} \cdot$ 塚田 順一 ${ }^{1}$ - 菊池 亮 ${ }^{1}$

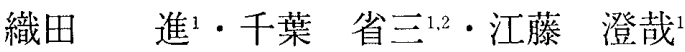

1産業医科大学第一内科学教室 2産業医科大学医療技術短期大学血液学

要 旨： 遺伝子組換え型インターロイキン 4 (IL-4)のマウス顆粒球・マクロファージ系前駆細胞 (CFU-GM) 堌殖に対する効果について，無血清抢よび血清培養法を用いて検討した。また， G-CSF, GM-CSF あるいは IL-3 による CFU-GM 形成に対する IL-4 の効果についても検討 した，1) 雨培養系において，IL-4 単独では CFU-GM コロニーを形成しなかった. 2) IL-4 は，無血清培養系において，全骨䯣細胞，非付着非貧食非 $\mathrm{T}$ 骨髄細胞あるいは 5 Fluorouracil 処理骨髄細胞からの, G-CSF, GM-CSF, IL-3 による CFU-GM コロニー形成を 抑制した，3) IL-4は，血清培養系では，非付着非貧食非 T 骨髄細胞を用いた場合, GMCSF 捛よびIL-3 による CFU-GM 形成を抑制したが, G-CSF による CFU-GM 形成を濃度 依存性に増加させた。 4) 雨培養系において, IL-4 は, 特に, GM-CSF, IL-3 による顆粒球系 コロニー形成を抑制した，G-CSF を同時添加した場合，IL-4は，無血清培養系では顆粒球 系コロニー形成を抑制し，マクロファージ系コロニー形成を相対的に増加させたが，血清 培養系では，マクロファージ系コロニー形成を著明に増加させた。以上の成績から, IL-4 は，血清の非存在下では，造血因子刺激 CFU-GM 増殖に対して抑制的に働くが，血清の 存在下では G-CSF 刺激 CFU-GM 形成を増加させる作用があることが明らかとなった。

J. UOEH（産業医大誌），12（2 )：163-174 (1990) 